\title{
THE HISTORICAL VALUE OF ACTS
}

\author{
W. Ward Gasque
}

During the past one hundred and fifty years of debate concerning the historical value of the Acts of the Apostles, few of those who have asserted opinions on the subject have actually done any primary research on the matter. Certainly, F. C. Baur (1792-1860), the Tübingen scholar who initiated an energetic attack on the trustworthiness of the Lucan account of Christian origins and whose long shadow continues to be cast across the contemporary discussion, did not. Searching the pages of the New Testament and the early Christian writings for texts to support his critical and historical assumptions, Baur never really took time either to engage in detailed exegesis or to do fundamental historical research (in the normal sense of that word), ${ }^{1}$ though admittedly the materials necessary for this task were only beginning to come to light as he worked. The same can be said for most of the early defenders of Luke's reliability on both sides of the Channel, with the exception of J. B. Lightfoot (1818-89). ${ }^{2}$ One had to wait for the work of Sir William M. Ramsay (1851-1939) 3 to see the beginning of the application of knowledge gained from the treasury of historical materials that was coming to light through the work

1 See W. W. Gasque, A History of the Interpretation of the Acts of the Apostles (Tübingen, J. C. B. Mohr 1975; reprinted Peabody, Hendrickson 1989) 27-54. I am unconvinced by P. C. Hodgson's attempt to defend Baur's method (The Formation of Historical Theology: A Study of F. C. Baur [New York, Harper \& Row 1966]). Cf. also S. Neill and T. Wright, The Interpretation of the New Testament 1861-1986 (New York, Oxford University Press 1988) 20-30, 5664.

2 Lightfoot was the first to begin to see the importance of the study of geography, inscriptions, coins, and the papyri, as well as the traditional literary documents for the interpretation of the New Testament. See his 'Discoveries Illustrating the Acts of the Apostles', first published in 1878 and included as an appendix to his Essays on the Work Entitled "Supernatural Religion" (London, Macmillan 1889) 291-302. See Gasque, History, 116-123; Neill and Wright, 37-64.

3 See W. W. Gasque, Sir William M. Ramsay: Archaeologist and New Testament Scholar (Grand Rapids, Baker 1966) and History, 136-42; cf. also Neill and Wright, 150-7. 
of archæologists and epigraphers and through the subsequent unearting of papyri and ostraca.

However, not even Ramsay made a complete study of the subject. His celebrated conversion to a more positive assessment of the writings of Luke led him to marshall an array of historical date in their defense, and he continued to produce a multitude of scholarly articles that provide both direct and indirect support for the essential historicity of Acts; ${ }^{4}$ but he never produced a systematic and complete treatment of the topic as a whole.

The only full investigation of the question of the historical value of Acts ever published was researched some seventy years ago, namely, the magisterial monograph by the distinguished German Catholic scholar, Alfred Wikenhauser (1883-1960). ${ }^{5}$ In spite of the work's careful, systematic, critical, and comprehensive nature it has rarely been referred to, much less been made full use of. Wikenhauser brings the research of classical historians and archæologists during the previous century into the discussion, and makes a close examination of the narrative of Acts in this light, as well as in the light of its own inter-connections. His conclusion is that the essential historicity of Acts is confirmed by both internal and external criteria. In the face of the links between the narrative of Acts and the letters of Paul, on the one hand, and the information we have concerning the historical, geographical, and cultural environment of the events related, on the other, it is extremely unlikely that the book is to any significant degree unhistorical.

The other major work to take an extensive look at the issue which drew on the new historical materials was The Beginnings of Christianity, edited by F. J. Foakes Jackson (1855$1941)$ and Kirsopp Lake (1872-1946). ${ }^{6}$ But, as so often is the case

4 My work on Ramsay (n. 3) includes a list of his writings that are relevant for New Testament research, along with indexes of subjects, Greek words, and key texts.

5 Die Apostelgeschichte und ihr Geschichtswert (NTAb VIII, 3-5, Münster in Westfalen, Aschendrofttische Verlagsbuchhandlung 1921). The work was essentially complete in 1918; cf. Gasque, History, 156-8.

65 vols. (New York, Macmillan 1920-33). The commentary (vol. IV) and additional notes (vol. V) make most extensive use of this material. The major contribution in terms of value is the work of Henry Joel Cadbury (1883-1974), 
with composite works, it was uneven in quality. H. J. Cadbury's comments and notes are especially valuable, but even these offer only a partial treatment of the historical and cultural background of the early Christian movement. The tendency of the contributors who were schooled in historical studies was to treat the world of the New Testament as a amalgam of Hellenistic and Roman ideas, with a bit of Judaism thrown in when you get as far east as the Province of Judæa. The orientalized Hellenism of the Eastern Empire that Ramsay had begun to unveil and that was becoming more widely known as a result of historical research, particularly through the myriads of inscriptional texts that were coming to light with each new season of excavations, was only touched on here and there.

The work on Acts that developed in Germany between the two World Wars and especially after the second World War came to focus on the theology of Acts more than on historical matters, though the three major contributors to the discussion-Martin Dibelius (1883-1947), 7 Ernst Haenchen (1894-1976), ${ }^{8}$ and Hans Conzelmann (1915-) ${ }^{9}$-all talked much about 'Luke the historian'. But by 'historian' they did not mean what Ramsay and the ancient historian, Eduard Meyer meant, viz., that the author of Acts was to be considered in the same league as Thucydides, Polybius and the greatest of the

who authored three other major works on Luke-Acts (The Style and Literary Method of Luke, 2 vols., [HTS 6, Cambridge, MA, Harvard University Press 1919-20]; The Making of Luke-Acts [New York, Macmillan 1928]; and The Book of Acts in History [London, A. \& C. Black 1955]); cf. Gasque, History, 168-94.

7 His most important essays, published between 1923 and 1947, are gathered together in his Aufätze zur Apostelgeschichte (Göttingen, Vandenhoeck \& Ruprecht 1951); ET Studies in the Acts of the Apostles (London, SCM Press 1956). On Dibelius, see Gasque, History, 201-35.

8 His weighty commentary (Die Apostelgeschichte, [KEK 3, Göttingen, Vandenhoeck \& Ruprecht 1977 (7th edn. $=16$ th edn.)]; ET [of 6th $=15$ th edn.]The Acts of the Apostles: A Commentary [Philadelphia, Fortress Press 1971]), first published in 1956 and revised several times, still exerts a major influence in the English-speaking world. Cf. Gasque, History, 235-47.

9 Although it is now quite dated (1963, rev. edn. 1972), his commentary in the HNT series, has now been translated into English and now forming a part of the Hermeneia series: Acts of the Apostles (Philadelphia, Fortress Press 1987). Cf. the review in Themelios 14/1 (Oct/Nov 1988) 30-1. 
Greek historians, ${ }^{10}$ but rather that Luke sought to interpret the traditions that had come down to him in a systematic and orderly manner so that the inner meaning of the events becomes clear to the church in his day. ${ }^{11} \mathrm{He}$ is a historian, it was argued, but he is an extremely creative historian-adapting, moulding, shaping, modifying, re-working, revising, and even creating tradition for his own theological purposes. By the time this generation of scholars had passed, it was not uncommon to object to the very idea of seeking to understand the purpose of the author of Acts as in any significant way an attempt to give a historically trustworthy account of the early Christian story, or even to approaching the text of Acts from a historian's perspective. ${ }^{12}$

With the exception of only a few major interpreters of Acts, ${ }^{13}$ recent research has tended to focus on the theological

10 'Sein Werk, trotz des viel kleinern Umfangs, [erhält] doch denselben Charakter wie die der großen Historiker, eines Polybios, eines Livius und so vieler anderer.' E. Meyer, Ursprung und Anfänge des Christentums 1 (Stuttgart \& Berlin, J. G. Cotta 1924) 2.

11 Cf. Dibelius' comment: 'Wir billigen ihm diesen [sc. Historiker] zu, weil er mehr getan hat, als Traditionsgut zu sammeln. Er hat auf seine Weise versucht, das in der Gemeinde Überlieferte und das von ihm selbst noch in Erfahrung Gebrachte in einem bedeutungsvollen Zusammenhang zu verknüpfen. Und er hat zweitens versucht, den Richtungssinn der Ereignisse sichtbar zu machen' (Aufsätze, 110).

12 Cf. P. Vielhauer's notorious comment in which he dismisses the value of Meyer's work because he came to the study of Acts 'with the presuppositions of a historian of antiquity', thus misunderstanding 'the nature of its accounts and the way in which they are connected' ('On the "Paulinism" of Acts', in L. E. Keck and J. L. Martyn (edd.), Studies in Luke-Acts (New York and Nashville, Abingdon 1966) 50. Similarly, see W. G. Kümmel's comments on Ramsay in The New Testament: The History of the Investigation of its Problems (ET; New York and Nashville, Abingdon 1973) 438.

13 Notably F. F. Bruce The Book of Acts (NICNT rev. edn., Grand Rapids, Eerdmans 1988); The Acts of the Apostles (Greek text: rev. edn., Grand Rapids, Eerdmans forthcoming 1989); and Paul: Apostle of the Free Spirit (Exeter, Paternoster 1977); I. H. Marshall, Luke: Historian and Theologian (Exeter, Paternoster 1970) and The Acts of the Apostles, (TNTC, Leicester, InterVarsity Press 1980); and M. Hengel, Zur urchirstlichen Geschichtsschreibung (Stuttgart, Calwer Verlag 1979) ET Acts and the History of Earliest Christianity (Philadelphia, Fortress Press 1980) and Between Jesus and Paul (Philadelphia, Fortress Press 1983). 
and literary art of Luke. ${ }^{14}$ It is noticable that the old hostility to the author and his schema has all but disappeared, and there even seems to be a renewed interest in the question of historicity, ${ }^{15}$ although in a more limited sense than would seem to be implied by the term. But still there has been no major treatment of the subject since Wikenhauser-until now. However, fresh off the press is a volume that fills this very large gap in a remarkable manner.

The late Colin J. Hemer (1930-87) will be well known to the readers of this journal. He was a classicist who gave up a career as a school teacher to devote himself to research on the background of the early Christian churches in Asia Minor and Greece. For nearly a quarter of a century he gave himself to the work of sifting through all the epigraphic, numismatic, papyrological, archæological, and geographical information concerning life in the cities associated with the Apocalypse of John, the letters of Paul, and the book of Acts that has become accessible in the present century-most of it quite unknown, except in a rather superficial and lexical manner, to New Testament specialists. In recent years he published a number of densely packed articles and essays in a wide variety of journals, ${ }^{16}$ was actively involved in the plans for the new 'Moulton

14 See F. Bovon, Luke the Theologian: Thirty-three years of research (19501983) (ET; Allison Park, Pickwick Publications 1987) and W. W. Gasque, 'A Fruitful Field: Recent Study of the Acts of the Apostles', Interp 42 (1988) 117-31. 15 See for example (in addition to Hengel): E. Plümacher, Lukas als hellenistischer Schriftsteller: (Göttingen, Vandenhoeck \& Ruprecht 1972); and, more recently, G. Lüdemann, Das frühe Christentum nach der Traditionen der Apostelgeschichte (Göttingen, Vandenhoeck \& Ruprecht 1987); forthcoming ET Early Christianity According to the Traditions in Acts (Philadelphia, Fortress Press 1989).

16 The most important of these for the study of Acts are 'The Sardis Letter and the Croesus Tradition', NTS 19 (1972-3) 94-7; 'Sulpicia, Satire 58-61', CR n.s. (1973) 12-13; 'The Edfu Ostraka and the Jewish Tax', PEQ 105 (1973) 6-12; 'Paul and Athens: A Topographical Note', NTS 20 (1974) 341-50; 'Alexandria Troas', TB 26 (1975) 79-112; 'Euraquilo and Melita', JTS n.s. 26 (1975) 100-11; 'The Adjective "Phrygia"', JTS n.s. 27 (1976) 122-6; 'Acts and Galatians Reconsidered', Themelios 2 (1976-7) 81-8; 'Phrygia: A Further Note', JTS n.s. (1977) 99-101; 'Luke the Historian', BJRL 60 (1977-8) 28-51; 'The Address of 1 Peter', ExpT 89 (1977-8) 239-43; 'The Manchester Rotas-Sator Square', FTh 105 (1978-9) 36-40; 'Observations on Pauline Chronology', in Pauline Studies: Essays presented to Professor F. F. Bruce on his 70th Birthday, edd. D. A. Hagner, M. J. Harris (Exeter, Paternoster 1980) 3-18; "The Pisidian Texts. A Problem of 
and Milligan' lexicon sponsored by Macquarie University, ${ }^{17}$ and produced a meticulously revised version of his doctoral dissertation on the life setting of the letters to the seven churches of Asia. ${ }^{18}$ In spite of his untimely death, the scholarly community can be very grateful that his magnum opus entitled, The Book of Acts in the Setting of Hellenistic History, ${ }^{19}$ was nearly complete and has now been prepared for publication by Conrad Gempf.

The work is similar in size and scope to Wikenhauser's monograph, though it is even more detailed and, of course, has access to seven decades of further historical research, each year of which has turned up hundreds of new Greek and Latin inscriptions and papyri. And Hemer seems to have combed through them all! The Index of Ancient Non-Literary Sources runs to seven double column pages and contains references to nearly a thousand different items. ${ }^{20}$ The Index of Ancient Literary Sources contains a similar number of references. This is not to say that he has neglected modern authors by any means, for he cites several thousand works by almost six hundred different biblical and historical researchers as well-and, more important, he gives evidence as having read and carefully interacted with each one.

Hemer's work consists of ten densely packed chapters and two appendices. The final chapter, summarizing the conclusions of the study, and the second appendix, discussing

Language and History', Kadmos 19 (1980) 54-64; 'First Person Narrative in Acts 27-28', TB 36 (1985) 79-109; 'The Name of Paul', TB 36 (1985) 179-83; 'Reflections on the Nature of New Testament Greek Vocabulary',TB 38 (1987) 65-92.

17 See his 'Towards a New Moulton and Milligan', NooT 24 (1982) 97-123. Cf. G. H. R. Horsley, New Testament Documents Illustrating Early Christianity 14, 1974-9 (North Ryde, Ancient History Documentary Research Centre, Macquarie University 1981-8).

18 The Letters to the Seven Churches of Asia in their Local Setting (JSNTSS 11, Sheffield, JSOT Press 1986). This work also contains an immense amount of material that is relevant for the study of the background to narrative and theology of Acts.

19 Edited by Conrad H. Gempf, (WUNT 49, Tübingen, J. C. B Mohr [Paul Siebeck] 1989), 482 + xiv pp.

20 By contrast, the index of Greek and Latin authors in Conzelmann's commentary (n. 9), which occupies 14 columns, lists less than fifty non-literary texts. 
the important inscription recently discovered at Aphrodisias that offers evidence for 'God-fearers', are by the editor.

Chapter one looks at the question of historicity. Hemer responds to those who believe that the question either has been settled in the past or is essentially irrelevant. He points out that the attempt to drive a wedge between history and theology offers a false antithesis. To recognize that Luke has theological aims in view in his writing, does not mean either that he might not also have historical aims, or that his theological concerns will have caused him to misrepresent the historical realities of the early Christian movement. Nor does the oft-repeated truism concerning the fact that Paul's letters offer 'primary' evidence for his life and that Acts is 'secondary' mean either that Paul's evidence is unbiased or that that of Acts is untrustworthy: both must be used and tested by the canons of historical criticism. If Acts is of little value for either an understanding of Paul's life and work or of the rest of the history of the early church, then we can know relatively little of early Christianity. Hemer argues that it is both uncritical and unwarranted to dismiss the material of Acts out of hand.

In chapter two Hemer looks at what he calls 'preliminary questions' to an investigation of the historicity of Acts, namely, the unity of Luke-Acts, the genre of Luke-Acts, the meaning of historicity, the proper manner of approaching the question, the textual problem (i.e. the wide divergences between the so-called Alexandrian and Western texts), and the materials that are available to serve as sources for the reconstruction of the social context of the narrative of Acts. Although the Acts of the Apostles is the second volume of a two volume work, it is different in type from the 'gospel' to which it is literarily connected. Hemer suggests that most of the recent suggestions concerning its genre-biography, memoir, apologia, encomium, aretalogy, 'false history,' novel or romance, midrash, lectionary-do not really fit, though he does not make it clear the label he would view as appropriate, unless it is 'history.' In any event, he makes it abundantly clear that the assumptions of many modern theologians-that the first century setting and obvious theological concerns of the book necessarily exclude its being taken seriously as a historical 
work-are fundamentally flawed. Contrary to popular belief, however, Hemer shows that there were recognized standards in the first century for evaluating works that purported to be works of history; and in many ways these were as rigorously 'critical', in principle if not always in practice, as modern conceptions. Therefore, we are perfectly justified in asking both whether the author lived up to these standards and whether we as modern people judge him to have succeeded in writing a work that is accurate, trustworthy, or reliable.

But how are we to test the author of Acts? Hemer offers eleven guidelines as to what might reasonably be expected in a writing like Acts. (1) We should focus on the author's qualities in general and principle rather than on a few details that seem to confirm or deny its accuracy. (2) We need to be concerned as to whether the author is habitually and in general a trustworthy source by the standards of his day, whether he exhibits accuracy or inaccuracy of mind, a general conscience for, or a general disregard of, historical fact' (p. 47). (3) We ought to decide whether the narrative offers 'an essentially accurate chronological outline' of the events that are being portrayed, while recognizing that there are other principles of arrangement which may be appropriate (p. 47). (4) We must allow for the use of natural, phenomenological language, which will lead to varying details and perspectives between two parallel historical sources. (5) The possibility of interlocking historical sources-e.g. Acts and the Epistles-should be considered. (6) Omission of detail is not to be regarded necessarily as evidence against historicity. (7) We have to face squarely the question of whether miracles happened. (8) We need to consider whether the substance of the speeches is authentic. (9) The degree of precision and approximation of the author's reporting of details should be evaluated. (10) The presence of theological motifs should not be seen as a disproof of historicity, for all sophisticated history is interpretive from its own perspective. (11) We should seek to be descriptive rather than definitive in our attempt to identify and evaluate the qualities of Acts in its own cultural context.

Hemer takes what he calls 'the contextual approach' to evaluating the historical value of Acts. The goal is to draw a social profile of the context of primitive Christianity, by a 
survey of the newly available non-literary materials, especially the inscriptions, analysed where possible by dates and individual cities, as well as the literature of the first century, in an attempt to understand the strength and rôle of Judaism in individual localities, local varieties of pagan religion and civic organization, customs and procedures, links with imperial history, and the like, and thus to provide a framework for appraising the narrative of Acts. In contrast to other historical periods, there are relatively few Greek literary sources that are actually contemporary: Strabo, Dionysius of Halicarnassus, Dioscorides, Josephus, Philo, Dio Chrysostom, Epictetus, and Plutarch, two of whom are Jewish while all the rest, save Plutarch are of Anatolian origin. The other names that survive from the period comprise epigrammatists in the Greek Anthology or are medical and historical writers known only from fragmentary citations. The Latin literature of the era ${ }^{21}$ is much richer but also of a different social ethos and quite remote from the everyday world of Luke and Paul. The most valuable material available, however, often comes from inscriptions, coins, papyri, archæology, and geography, though the literary references should also be used where appropriate.22 Hemer points out that more than five thousand inscriptions from the city of Ephesus alone have been published, not to mention the important coins, and that this is but one of hundreds of Græco-Roman cities that offer a thesaurus of information to the diligent researcher.

Chapter three looks at the question of ancient historiography. Here Hemer demonstrates how little some theologians know of even the primary literary documents, for there is a great deal of evidence that goes against the assumption that there were no careful standards in Luke's time.

21 Lucan, Martial, Persius, Petronius, Pliny the Elder, Seneca, Quintilian, Statius, Juvenal, Pliny the Younger, Suetonius, Tacitus, Celsus, Columella, Frontinus, Manilius, and Scribonius Largus.

22 It is worth noting that Conzelmann (n. 9) cites primarily literary references, spanning the centuries, and that they tend to be lexical rather than contextual. Those by R. I. Pervo, Profit With Delight: The Literary Genre of the Acts of the Apostles (Philadelphia, Fortress Press 1987) are practically all literary, though he stresses more popular literature; and they are more contextual. 
Calling attention to an important sequence of articles by G. Schepens, he argues that there was a rather sophisticated scholarship on the topic, even if was somewhat differently conceived than in our day. These traditions laid stress on the importance of eyewitness participation in the events narrated, the value of interviewing other eye-witnesses, the limitation of coverage to material where the writer has trustworthy information, travel to the scene of events in an attempt to understand the situation adequately, checking details by means of contemporary documents, occasional insistence on the use of sources for speeches, and the idea of 'truth' in history 'as it actually happened'. ${ }^{23}$ This is followed by a careful analysis of how historians in antiquity actually went about their worktheir varying conceptions, selection of sources and traditions, the order and arrangement of their narratives, use of speeches, ${ }^{24}$ moral and religious assumptions underlying their undertakings, attitudes toward bias, and understanding of the qualifications of the historian. The chapter is concluded with a discussion of Luke's relation to Josephus (94-9), in which the differences rather than the similarities between the two writers are underlined, with Josephus proving to be the less reliable historian, even when he is talking about events in which he participated as an eyewitness.

Chapter four introduces sixteen categories of details in Acts that can be correlated with external sources. There are (1) items of geographical detail and the like which may be assumed to have been generally known at the time of writing, (2) specialized details known to those who possessed relevant experience (e.g. titles of Roman government officials, army personnel, major travel routes, etc.), and (3) specific details that are unlikely to have been known except to a person who had visited certain localities (e.g. local routes, boundaries, titles of city officials, etc.). (4) Dates of known kings and governors may be linked with the ostensible chronology of Acts.

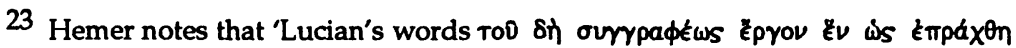
$\epsilon l \pi \epsilon t$ (de Hist. Conscrib. 39) are almost exactly the same as Ranke's wie es eigentlich gewesen' (91). He further notes that eigentlich in 19th century German meant 'essentially' rather than 'actually.'

24 Hemer comments: 'It is by no means true that all ancient historians felt free to put fictitious speeches in the mouths of historical characters' (75). 
Then, there are (5) possible details that fit the dramatic date of Paul or a hypothetical date for Luke. And, in contrast to the well known items that make it difficult to correlate the narrative of Acts and the letters of Paul, there are the much more (6) numerous 'undesigned coincidences' between the independently written Acts and the Epistles, agreements in matters of incidental detail that are of no central importance either to the narrative of Acts or to Paul's letters. (7) The incidental details within the Lucan narrative that correlate to one another implicitly without reflection of any self-consciousness on the part of the author would offer another variety of evidence. There are also (8) the independently attested details which agree with one of the two text traditions against the other and where a secondary reading may refer anachronistically to differing conditions of a later historical period, (9) matters of common local knowledge that are mentioned informally or allusively in a manner that indicates familiarity, (10) the differences in formulation within Acts that might indicate different types of sources, (11) peculiarities in the selection of detail that cannot be attributed to theological concerns but which may be explained historically, (12) details whose sense of immediacy suggest the author's reproduction of recent experience rather than redactional concerns, (13) reflections of first century culture and idiom rather than a second century atmosphere, (14) interrelated details in which two or more kinds of correlation are combined to build a larger fragment of historical reconstruction, (15) cases where the progress of discovery and knowledge provides new background information, and (16) precise details that lie within the range of contemporary possibilities but whose particular accuracy can neither be verified or disproved.

The first two of these categories contribute little toward demonstrating the historicity of Acts. These include items such as the emperor's title 'Augustus' ( $\delta \Sigma \epsilon \beta a \sigma \tau \delta s$ [25:21, 25], rendered as a name [Av̌ yourtos] bestowed on the first emperor in Luke 2:1, a distinction that is common), the general facts of navigation and corn-supply that are exemplified by the voyage of an Alexandrian ship to Puteoli (27:6-28:13), and the explanation of Judæan topography and Semitic nomenclature 
(1:12, 19, etc.) but not basic Jewish institutions (1:12; 2:1; 4:1, etc.).

Category (3) includes matters such as the topography of Jerusalem, ${ }^{25}$ Annas' continued prestige and bearing of the title of high priest after his formal deposition by the Romans and the appointment of Caiaphas, the organization of a military guard (12:4), the proconsular/senatorial status of the province of Cyprus at the time of Paul's visit (13:7), the part played by Troas in the system of communication (16:8ff.), the identification of Amphipolis and Apollonia (17:1) as stations on the Egnatian Way from Philippi to Thessalonica, and many of the details in the geography and navigational details of the voyage to Rome (chs. 27-8). The latter provides much grist for Hemer's mill throughout the monograph, calling into question the hypothesis that this portion of Acts represents an alleged sea voyage genre of Greek literature.

The bulk of chapter four is given over to illustrate the overwhelming evidence indicated by the specific details of Acts 13-28 that support the view that the author possessed an intimate knowledge of the local circumstances of the setting for his narration (108-58). In a brief review it is impossible to give more than a few of the several hundred examples of details unlikely to have been known except to a person who had visited the localities under discussion, but these will indicate something of both the richness of the data and the painstaking care with which Hemer has done his work. From chapters 1314 we have the following: the narrator indicates a natural crossing between two correctly named ports (13:4-5). Although the actual name of the proconsul of Cyprus cannot be confirmed and attempts to find extra-biblical evidence for his family's link with the Christian community cannot be sustained, the family of the Sergii Pauli is attested (13:7). Perga (13:13), a river port, is a plausible direct destination of a ship crossing from Cyprus, whereas a 'coaster' would have called only at the coastal harbour town of Attalia. The reading of the Alexan-

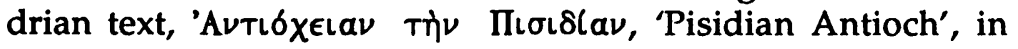

25 Cf. M. Hengel, 'Der Historiker Lukas und die Geographie Palästinas in der Apostelgeschichte,' ZDPV 89 (1983) 147-83 = Between Jesus and Paul, 97-128, 190-210. 
13:14 represents a correct designation of the city which could be

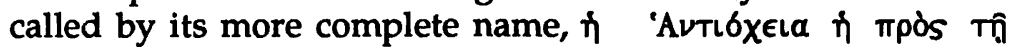
$\Pi\llcorner\sigma\llcorner\delta l a$, which was at this time in Phrygia rather than Pisidia. Acts 14:6 implies that Iconium was not in Lycaonia, as many exegetes 'have often presupposed on the strength of sources reflecting boundary changes and conditions of a later date, a fact confirmed by the geographical distribution of NeoPhrygian texts and onomastic investigation' (see 228-30). The Lycaonian language is spoken at Lystra (14:11); this would have been unusual in most of the cosmopolitan cities that Paul was at home in, but this was appropriate for a Roman colony in a less developed part of Anatolia and is attested in a gloss in Stephanus of Byzantium. The cultic tie between gods hellenized as Zeus and Hermes (14:12) is paralleled by inscriptions from Lystra and the nearby district, and the identification of Paul and Barnabas with the two gods corresponds to the local conception of the two gods. The character of the appeal of the apostles to the people in 14:15-17 fits the occasion and the context of Anatolian religion, whatever one thinks of its correlation to the theology in Paul's epistles. The travellers return to Attalia (14:25) to intercept a coasting vessel back to Syria, which is just as it should be.

Illustrations of the same kind can be given for Acts 16 . Derbe first and then Lystra (16:1) is the correct order of approach overland from the Cilician Gates. Lystra and Iconium were relatively close together, although they belonged to different jurisdictions, whereas Derbe is now known to have been more distant than was previously supposed by scholars; thus it is natural that Timothy, if his home were Lystra, would be known to these two churches rather than in Derbe (16:2). Although it is a much debated phrase, 'the Phrygian and Galatian country' (16:6) may be taken to denote 'Phrygia Galatica,' as Hemer has demonstrated at some length on the basis of geographical and epigraphical research. ${ }^{26}$ The form of the name of Troas (16:8) is given correctly as current in the first century. The manner in which Troas is cited as a destination that would open the door to a variety of opportunities meshes

26 See his two notes in JTS n.s. 27 (1976) 122-6 and n.s. 28 (1977) 99-101, as well as the detailed discussion in his The Book of Acts, 112 et passim. 
with the fact that it was a key point on the Roman system of communication at that time. Samothrace (16:11), dominated by a 5,000 foot mountain, was a conspicuous landmark for sailors in the region. Philippi is correctly described as a Roman colony (16:12), a fact abundantly attested by its predominantly Latin epigraphy using the explicit titles and magistracies that are appropriate; and the author names its seaport correctly as

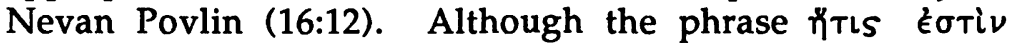

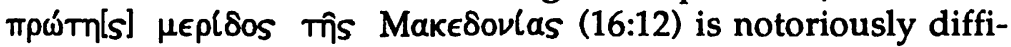
cult in the face of the divergent manuscript readings, the city in fact belongs to the 'first' of the four $\mu \epsilon \rho \imath \delta \epsilon s$, 'precisely suiting $\pi \rho \omega$ TnS $\mu \epsilon \rho(\delta 0 S$, if that emendation from some of the versions be accepted' (113). The Gangites, a small river flows lose to the walls of Philippi, a colony rather than a commercial center at the time and which was therefore unlikely to have a large Jewish community (16:13). The woman Lydia was from Thyatira in Lydia, thus the appropriateness of her name (16:14), which may, in fact, be an ethnic cognomen ('the Lydian woman') rather than her proper name; the name is attested both as a regular and as an alternative name $(114,231)$. Thyatira is attested by at least seven inscriptions to be a center of dyeing (16:14), and a commercial connection between the dyeing industries of Thyatira and Macedonia is also attested. 16:20-1 offers an ironical treatment of the anti-Jewish feeling on the part of colonists proud of their status as Romans. The chief magistrates of Philippi are properly designated oтpatayol (16:22), following the general term dpXovTES (16:9). The use of the term for the duoviri of a colony is attested at Pisidian Antioch, and the flogging portrayed by Luke is appropriate to the $\rho \alpha \beta \delta \circ 0$ xol $(16: 35)$ or lictores attendant on colonial magistrates.

This sort of detail is documented by Hemer for the whole of Acts 13-28 (except for ch. 15!). It would be easy to dismiss a few examples of this pattern or to suggest that they are trivial, but when one is confronted by case after case it is difficult to be sceptical. The scant outline that has been included above does not do justice to the copious and meticulously researched details furnished by Hemer One must consult his monograph directly. It is no exaggeration to suggest that henceforth no serious commentator on Acts will be able to 
deal adequately with the book without this work constantly at his or her side.

And this is but the beginning! Hemer continues his sifting of the data of Acts and the extra-canonical materials for another 284 pages, taking the reader carefully through each of the categories of possible correlations. The section entitled 'Correlations of Date with Ostensible Chronology' (159-75) treats the synchronisms of Luke 3:1-2 and 3:23, the date of the crucifixion (Luke 23:54), the joint naming of Annas and Caiaphas in Acts 4:6 (appropriate prior to the deposition of Caiaphas in AD 36), Gamaliel $(5: 34 ; 22: 3)$, the Theudas crux $(5: 36)$, the Judas who is mentioned in the same context $(5: 37)$, Candace (8:27, a title rather than a name), Paul's escape from Damascus (9:24-5), the 'Italic cohort' (10:1), the famine under Claudius (11:28), Herod Agrippa I (12:1) and his death in AD 44 (12:20-3), Manaen (Menahem, 13:1), Sergius Paulus (13:7), the 'decrees of Caesar' against which Paul was accused of offending (17:7), the expulsion of the Jews from Rome by Claudius (18:2), the proconsulship of Gallio in Achaia (18:12), the plural d 20 0 interregnum following the murder of Julius Silanus in October AD 54?), the 'fairly full conspectus of the travel diary of a seven-week period between Passover and Pentecost' (169) found

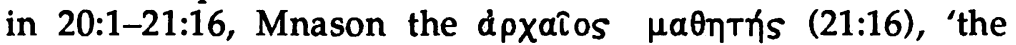
Egyptian' (21:38), the fact that the XLXlapXos had brought his citizenship at great cost (22:28), the high priest Ananias (23:2), Felix (23:24), Felix's relation with Paul in view of his Cilician home (23:34), Paul's reference to Felix's having judged the nation ejk mollw'n eJtw'n (24:10), Drusilla as the wife of Felix (24:24), the two years in which Paul remained in custody in Caesarea (24:27), Bernice as consort of Agrippa II (25:13), the $\sigma \pi \epsilon \hat{\text { pa }} \Sigma \epsilon \beta a \sigma \pi$ (27:1), the reference to the Fast (27:9), the $\delta\llcorner\in T l \alpha$ at the end of the narrative of Acts (28:30). Although some of these chronological indications 'are too slight and uncertain to be of more than marginal value' they tend to fit together-with the one exception of the reference to Theudasinto 'an approximate ostensible outline of the internal chronology, and this fit becomes unexpectedly specific and precise for the period $57-62^{\prime}$ (175). Thus, while the author does 
not give us everything that the historical researcher might desire, he does give us much more than many have dreamed of.

Details broadly suggestive of a first century date include the following: the prominence of the Sadducees (4:1; etc.) points to a pre-AD 70 setting. The 'Hellenists' (6:1ff.), however they are defined, belong to the earliest period of the church. The 'Synagogue of the Freedmen' (6:9) might be the one of Theodotus in the Ophel inscription (CIJ 1404), certainly predating $A D$ 70. The views of Stephen (7:2-53) can be best explained as involving a radical critique of official Judaism in a setting when the Temple yet stood. The stoning of Stephen (7:57ff.), although both irregular and illegal, fits well with Paul's sense of personal guilt as a persecutor of the church (1 Cor. 5:9; Gal. 1:13, 23; Phil. 3:6; cf. Acts 22:20); at the very least it is suitable to the dramatic period, the troubled last years of Pilate. The violence of the reaction to Stephen (8:1) coheres with his implied attack on the Temple and the Jerusalem priesthood. The reference to Simon Magus (8:9) might offer a broadly linked date if the traditions preserved by Justin Martyr, a native of Neapolis in Samaria, who dates this in the reign of Claudius, are correct. Use of the simple nomen Cornelius (10:1) reflects an older Roman practice that continued into the Julio-Claudian period among more conservatively minded soldiers. The date of the coining of the term 'Christian' was likely early, certainly prior to the great Roman fire of $\mathrm{AD}$ 64 (Tacitus Ann. 15.44). The Gentile 'God-fearers' (13:16) who are found attaching themselves to the synagogues of the Diaspora, whether reflecting technical terms or not, fits the pre-AD 70 period better than the period immediately following the Jewish War. ${ }^{27}$ The location of Iconium outside of Lycaonia (14:6) fits a first century rather than a later date. The predominance of the Lycaonia language (14:11) suggests an earlier rather than later date, since the indigenous languages of Asia Minor were rapidly displaced by Greek and the official Latin. The association of Pisidian Antioch, Iconium and Lystra,

27 Hemer and Gempf challenge the views of A. T. Kraabel and others who deny the very existence of such a category of people attached to the synagogue, and the evidence of the newly published inscription from Aphrodisias seems to sustain this objection (see Appendix 2, by C. Gempf, 444-7). 
all Phrygian cities, linked by the Roman road and defence system and in adjacent southern districts of the province of Galatia speaks of a first century setting.

Selectively, other signs of first century rather than later practices include: The use of the name Troas (16:8), the character of Gallio's response (18:15) as well as the accusation advanced against Paul and his associates (18:13), the designation of certain men by their province as 'Aolavol, Paul's practice of Jewish piety (21:23-4), the accusation of Temple defilement (21:28), the reference to the sicarii (21:38), the application of the lex Iulia de vi publica for the protection of Roman citizens from abuse by persons in authority $(22: 25,29)$, the purchasing of (and consequent devaluing of) citizenship under Claudius (22:28), the assumption of Claudius Lysias that Christianity lay within the protection guaranteed to Judaism (23:29), Paul's defence which stresses his strict Jewish faith (24:14), the form of Paul's appeal to Caesar (25:11). ${ }^{28}$

As far as the correlations between Acts and the Epistles are concerned, they are extensive. Hemer lists sixty-six different interconnecting links, many of them multi-related, between the narrative and Acts and the letters of Paul (181-90). These are not intended to be exhaustive, and those that would be thought to be speculative are excluded. The result is impressive.

The author continues by enumerating selected internal correlations between the different sections of the book. What this amounts to is a joint-witness of two or more apparent traditions within the narrative of Acts. Examples include the references to Jesus as a descendant of David in two different sermons to Jewish audiences by different persons (2:29-30; 13:223; absent from other speeches), Philip's being left in Caesarea and subsequently reappearing in the same city (8:40; $21: 8$; cf. 6:5), Agabus' appearance in both the early part of Acts and in the 'we'-sections $(11: 28 ; 21: 10)$, the stress on regular Jewish preaching on the Sabbath in different kinds of contexts (13:27,

28 It is noteworthy that the foremost authority on Roman citizenship makes the point that Luke's portrayal of Paul appeal fits the practice of provocatio current in this period (A. N. Sherwin-White, Roman Society and Roman Law in the New Testament [Oxford, Clarendon 1963] 63-70). 
15:21), inter alia. Then, there are the details involving differences between the Alexandrian and Western texts, which, incidentally, tell against the reliability of the latter; ${ }^{29}$ the 'unstudied allusions' mentioned by the author in an informal manner so as to seem highly unlikely that they have been consciously included; differences of terminology within Acts that might provide clues for the use of different types of historical sources, such as the variety of geographical, political, and religious terminology (e.g. the two spellings of Jerusalem and the use of personal names in the Pauline contingent); seemingly unnecessary detail that does not lend itself to a theological explanation; the 'immediacy in details' that is not easily explained by reference to the perspective of selective hindsight (especially the material in the 'we'-narratives, and above all the sea voyage and shipwreck, contra the hypothesis of a 'seavoyage' genre) $)^{30}$; characteristics of language and cultural understandings that suggest a first-century date of composition; and multi-related categories of interrelated details, e.g. the information concerning Paul's time at Corinth and also his escape from Damascus.

A most valuable excursive is appended to chapter five, dealing with the names and titles in Acts (221-43). Again, Hemer proves to be a master of careful detail and offers us all the key names and titles in the whole of Acts. As one who knows the literature, let me say that there is no commentary or

29 The generalized conclusion from these gleanings must be that in no case can we with confidence take a Western reading as a basic datum. In some places a secondary text may preserve correct traditions of inferences, but they cannot be given higher status, nor be used as a convenience to suit an argument. Yet the type has a pedigree as a revision; its antecedents can be traced to the second century. The reviser had some knowledge of Asia Minor, as passages touching Lystra, Ephesus, Trogyllium and elsewhere can show' (200).

30 Hemer, here and elsewhere, demonstrates the untenable nature of the arguments of V. K. Robbins ('The We-Passages in Acts and Ancient SeaVoyages', BibRes 20 [1975] 5-18; 'By Land and By Sea: The We-Passages and Ancient Sea Voyages', in Perspectives in Luke-Acts, ed. C. H. Talbert [Danville, Association of Baptist Professors of Religion 1978) 215-42]) and others both for the existence of a literary genre of the type suggested and for the idea that Luke's material might fit into this alleged pattern. In an understatement, he comments: 'His [sc. Robbins] examples are not necessarily representative, nor are they always taken correctly in context, nor are they subject to control, nor do they prove the conclusions he draws from them' (317). Cf. 317-21; and 'First Person Narrative in Acts 27-28, TB 36 (1985) 79-109. 
reference work anywhere that gathers anything approaching all this information under one heading. In fact, there is no one library anywhere that I know of that would offer this detail, since much of it reflects the author's investigation of and meditation on the primary historical evidence, including the non-literary documents that had to be searched out among all the mass of published (and unpublished!) materials.

The sixth chapter seeks to relate the data of the Acts and the letters of Paul in a systematic manner. He begins by confronting the theological differences between Luke and Paul, which he regards as real but vastly overstated and used in an inappropriate fashion, to create alleged historical problems where few historians would see them. In spite of the strictures of John Knox ${ }^{31}$ and others, he does not hesitate to attempt to develop a chronology for both Paul and the early Christian movement, though he recognizes the difficulties in the task. Still, he has earlier piled up evidence in favour of the view that there are important chronological data that interlock with both the secular history of the time and the other New Testament materials, so he seeks to work out a tentative chronological framework and then seeks to integrate the various events and documents into it.

Chapter seven focuses on the Galatian question. It is hard for a classicist like Hemer to understand how anyone could continue to defend the old North Galatian theory, but he tries hard. Although the historicity of Acts does not stand or fall with the South Galatian theory, the theory does solve some difficulties; and just about all the evidence points in this direction, some of it conclusively-at least as far as those who are conversant with the geography and non-literary texts are concerned. Hemer presents a detailed and (to me) convincing case that the dictum of J. A. Findlay still stands: 'It is significant that all those who know the geography of Asia Minor well are "South Galatianists" to a man. ${ }^{32}$

31 Chapters in a Life of Paul (New York and Nashville, Abingdon Press 1950).

32 From his commentary on The Acts of the Apostles (London, SCM 1934), 166; quoted in F. F. Bruce, Epistle to the Galatians (NIGTC, Exeter, Paternoster 1982) 8. 
Chapter eight treats the question of the author and his sources. Contrary to contemporary trends, at least in North America and Germany (with notable exceptions), Hemer finds the evidence overwhelming against the alternative theories concerning the significance of the 'we'-passages and in favour of the view that the author was in fact an eye-witness to many of the events in the second half of the book and in a position, especially during the period AD 57-9 when he was ostensibly in and around Palestine, to interview numerous eye-witnesses and those who were in touch with the earliest generation. Hemer does not argue this on any particular theological or traditional ground, but rather on the basis of his attempt to make sense of the historical data. The alternative views seem, in his opinion, to be cases based on faulty logic, as well as wrong-headed interpretations of extra-biblical data, frequently assuming the conclusions supposedly under investigation.

In chapter nine Hemer looks at the question of the date of Acts in the light of all the evidence that he has attempted to process. Again, contrary to the majority opinion, he opts for the early date of $\mathrm{AD} 62$, concurrent with the situation at the end of its narration. Those who have been brought up on Haenchen will doubtless find this hard to swallow (if they have patience to read this far), but no one taking any date, whether early or late, has ever marshalled the detailed evidence in the way that Hemer has done. One is, of course, free to differ with him in the matter-and I, for one, am not totally convinced-but he or she cannot claim to be a thoroughly critical scholar without weighing the evidence that he has brought forward and offering alternative interpretations. In many ways, there is much more evidence for the early date contained in his work than in the forty-five pages dedicated exclusively to the subject, for it is the material that has been paraded throughout his study, when taken as a whole, that he, believes, drives him to this as the only viable conclusion. And although it is as possible to take a very low 
view of the historical value of Acts while dating it early ${ }^{33}$ as it is to take a high view of the historical worth of Acts while dating it relatively late, ${ }^{34}$ it is likely that those who are impressed by the weight of Hemer's argument for the essential historicity will wish to take a fresh look at his arguments in favour of the early date.

The Book of Acts in the Setting of Hellenistic History is a tour de force. This work meets a long felt need and one that few contemporary New Testament researchers are adequately equipped to write. Most Bible scholars today simply do not have control of the languages, not to mention a first hand knowledge of the documents, either literary or non-literary. Those who do seek to draw on the secular and religious material that is available to use in interpreting the milieu of early Christianity are all too frequently limited to taking an approach that is based primarily on anthologies and lexica, thus neglecting both immediate context and access to the valuable material that has come to light through modern classical archæological research. For most of us who are thus restricted by the limitations of our contemporary educational practices, Hemer has provided an immense service. We shall be indebted to him for many years to come. For younger men and women who are just beginning their life's work as students and teachers of the New Testament and early Christian writings, he has provided and inspiration and a model.

If there is a limitation to Hemer's work, it is that the bulk of his evidence is related to Acts 13-28 (with only scanty attention paid to Acts 15). While he gives what will be regarded by many as a convincing case for essential historicity of the so-called Pauline section of Acts and even the broad outline of the events narrated in chapters 1-12, the corresponding detail that would support the material of the earlier chapters is missing. True, there are important

33 Cf. E. R. Goodenough in his essay in Studies in Luke-Acts (n. 12), who dated Acts at about the same time as Hemer dates it, but regards it as a highly tendentious work of questionable historical worth.

34 Cf. e.g. D. J. Williams (ca. AD 75), A. Plummer (no later than AD 80), A. A. T. Ehrhardt (AD 75-90), H. A. W. Meyer (ca. AD 80), W. M. Ramsay (AD 81), G. Schneider (AD 80-90), F. J. Foakes Jackson (before ca. AD 90), B. H. Streeter (ca. AD 90-95), etc. 
exceptions, but the impression remains that the Luke's knowledge of the period is rather vague and imprecise as compared with that of the latter period, and Hemer himself is not as much at home in working with the Jewish materials (other than Josephus) that would provide much of the background to this period.

Hemer would probably reply that this is precisely what one one expect-if they 'we'-narratives are interpreted in their normal sense, for the author was himself an active participant in many of the events of the period covered by the second half of the book. Furthermore, he is writing an account of the Book of Acts 'in the setting of hellenistic history'. But this is probably not sufficient to tell the whole story. What is needed now is a companion volume entitled, The Book of Acts in the Setting of Early Judaism!

Furthermore, if others err in the direction of devaluing the historicity of Acts and the cultural environment of the early church, Hemer goes in the opposite direction of undervaluing, or at least not paying a great deal of attention to, the theological concerns of the author and the diverse currents in early Christian doctrine. Again, he would probably demur and confess (in the tradition of his teacher, F. F. Bruce): 'But I'm not a theologian. In any event, I am writing a work of history, not theology!' But as he himself has pointed out several times in the course of his monumental monograph, history and theology are not mutually exclusive. It is possible for them to be co-labourers together in the cause of the Gospel. After all, it was the author of Luke-Acts who first saw this most clearly.

Nevertheless, with this minor caveat, I warmly commend Hemer's work to all who are concerned to interpret the Acts of the Apostles. The book is magnificently produced (I could find only a couple of typos!), and in spite of its expensive price, it can be said without hesitation that it is worth every pfennig! It only remains now to see that the results of his research are incorporated into the major commentaries on Acts so that they will be available to a wider audience. 